\title{
The Atrides Saga and Power Play: The Dilemma Between Freedom and Death on the Theatrical Scene
}

\author{
Maria Sgouridou \\ Stefan Lindinger
}

Georgios Bitsakos

National and Kapodistrian University of Athens, School of Philosophy*

Abstract

Thyestes' myth is difficult to read: cruel, abominable, but also multidimensional. And this is why it is adaptable to multiple interpretations, highlighting the different aspects of tyranny within different political, socio-cultural and philosophical contexts during the centuries. Thyestes, the protagonist of the tragedy, serves, with his unique characteristics, as an example to the spectator in order to understand and improve his own situation, even his very existence. First, we will take a look upon the theatrical production by Petros Katsaitis, author of a tragedy based upon this myth in 1721. At that time, Greece does not yet exist as a national state, being under the rule of the Ottoman Empire. Thus, Katsaitis highlights the complex historical reality in which he lives in person. The German author Christian Felix Weiße writes his Atreus und Thyest in 1766 in the philosophical context of Enlightenment, with a focus on the anthropological education of his audience. Ugo Foscolo, being between Italy and Greece, between Neoclassicism and Romanticism, in his Tieste (1797) recalls the memories of modernity's Ancient Greek roots and re-elaborates the myth by reinvesting it with civil and political sense. Thus, the purpose of this paper is to present three versions of an ancient Greek myth composed during the eighteenth-century in three different regions of Europe in order to highlight the potential impact of this tragedy on the viewer's reception and in relation to the historical-cultural and philosophical trends of the time.

Keywords: Thiestes, Tragedy, Weiße, Katsaitis, Foscolo.

\section{Introduction}

Among the Greek myths that take place in the Heroic Age is the story of the House of Atreus. The Atreus and Thyestes myth, although it is one of the most violent and cruel of the Greek antiquity, inspired the European theatre and influenced the artistic production of many writers: Latin, French, German, Italian and others. The roots of the myth must be searched at the beginning of the ancient tradition and the artists' first efforts at the demanding campus of Literature. We find the first citation regarding the two brothers in Homer's lliad (B' v.v. 100-108) ${ }^{1}$. In this particular text, the myth is not full and clearly described, in other words not perfectly elaborated yet. Homer, in his epic poem, dedicates these verses to the governors before Agamemnon, and among them, to Atreus and Thyestes. The initial construction of the story does not provoke fear but is mainly focused at the political game: Pelops, the hero that gave his name to Peloponnesus, a beautiful region extending at the southern part of Greece, was married to the princess Hippodamia and had six sons from her. But the king had also another son, named Chrysippus, with a nymph. Queen Hippodamia killed him, supported by her twins Atreus and Thyestes. According to the most diffused version if the myth, Chryssipus, before his death, revealed to his father who the murderers were. The father asked from the Gods to punish them and exiled his sons from the kingdom. After his death, they returned, and Atreus took the throne as legal heritance because he was the older. Hermes gave to him, as a symbol of authority, a Golden Fleece and this donation was the revenge of the Gods for Chryssipus' murder: Thyestes, jealous of his own brother, cooperated with his wife Aërope, stole the Golden Fleece, and asked from the people the authority. The gods, furious about Thyestes behavior, demanded from the Sun to change the usual orbit of the day. When Atreus realized the meaning of the omen, he killed his wife and exiled his brother. As we can see so far, everything has to do with power, but after this particular point, the situation became much more realistic and dramatic. The plot of the myth is rather

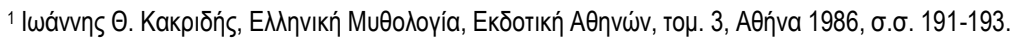


unexpected, since the tragic poets of Athens, formed it in a different way, insisted upon the mutual hate between the two brothers. A few years later, Thyestes returns with his sons, imploring forgiveness and reconciliation with his brother. But king Atreus' extreme behavior aggravates the situation, up to the tragic solution: he kills Thyestes' children and offers their own flesh and blood, as a supper to their father. Other sources -regarding theatre- about the reconstruction if the initial myth, are: Aeschylus' Agamemnon (v.v. 1217-1244), Ajax of Sophocles (v.v. 1291-1297), Electra and Orestes of Euripides ${ }^{1}$ (v.v. 718-736). From the Latin theatre, there are six well-known authors who occupied themselves with the myth, such as Ennius, Accius, Varius Rufus, and -of course- the great Seneca: his Thyestes is the only one preserved in its entirety, of all above mentioned ${ }^{2}$. It is rather difficult to find out which was the original text that served as a model for Seneca. Although we all know the most famous tragedies that include elements of the Atrides initial version, unfortunately, there is no attic tragedy, saved as a whole, which is inspired exclusively by the characters of Atreus and Thyestes. We know, for example, that Sophocles composed three or four tragedies regarding this particular myth, but we don't know anything about their plot or the way he decided to elaborate his material. The most of the researchers agree that the tragic poet, probably focused upon the original story of the Golden Fleece in his lost tragedy entitled Atreus, the sacrifice of his brother's sons in a tragedy with the title Thyestes. Furthermore it has to be reported that there existed six other tragedies, composed between 5 th and 4 th century inspired from Atreus and Thyestes myth ${ }^{3}$. Also Euripides has composed a tragedy with Thyestes as the central figure. Unfortunately nothing more than a little number of verses is saved from this work. Euripides, the most tragic poet of the antiquity, creates his hero -and many others-a beggar. Probably the main issue is focused upon the terrible supper, and according to the sources it was presented in 425 a.C. because in Aristofanes' Aharnes there is a citation to Euripides Thyestes ${ }^{4}$. So it is obvious why we are not able to find out the author or the work that influenced Seneca. In any case, we cannot speak for a simple translation of a Greek model or a revision. Except the traces of the ancient myth-or the "unknown" tragedy- we are able to recognize in Seneca's tragedy, some scenes from Virgil's Eneide and the Transformations of Ovidius. The presence of the Latin literature coexists with the Greek tradition in Seneca's Thyestes. This tragedy of 1112 verses insists upon the relationship between the king and his twin brother, the death of the innocent children and the famous supper. The main subject of the work is the passion for the unconceivable, an enormous desire for power, authority, blood and domination over other people's destiny. Dreams never accomplished. This is the base of all modern dramatic productions in Italy and Greece regarding Thyestes. For example, after Seneca comes Lodovico Dolce with his particular drama Thyestes ${ }^{5}$, a typical product of the $16^{\text {th }}$ century (was written in 1543), the period of Humanism. In this text, the presence of Seneca is more than obvious. Thyestes was his second tragedy and Dolce-editor, translator, curator and criticrepresents the spirit of Renaissance, promoting the "Ars mimetica", and creates a revision if the Latin tragedy. Dolce became the model for Peter Katsaitis, who composed his own Thyestes in 1721, expressive of the Greek Barock period". The divergence among these three works, are characteristic of the different ages they belong: In the Latin tragedy, there is no hope if justice and although the hero implores the Gods for revenge, the punishment of the guilty never arrives. On the contrary, the Italian work develops the main story from another point of view: As the message is based on Christianity, the hero believes that a God full of compassion will save him from the pain and the Purification from the kings' crime will sooner or later take place. In this version of the plot, the problem between the two brothers starts for another reason, totally different from tradition: The commitment of adultery by Thyestes and the queen Aërope. Because of this old sin Atreus cannot find the peace, is not sure about the paternity of his own children, hates his brother to the death, and takes his horrible revenge. Katsaitis follows the same version of the myth up to a certain point: Sometimes, he just makes a translation of the Italian tragedy, but in many other cases, he prefers to follow his own inspiration. For example, he starts out with a long introductiona Prologue- that makes a symbolic figure, the Justice. Also, at the end of the drama, in 762 verses that not exist in the Latin and the Italian work, the Greek poet describes Atreus' death, twenty years later, by Aegisthus and Clytemnestra. Katsaitis

\footnotetext{
1 lbid.

2 John G. Fitch, Seneca. Oedipus. Agamemnon, Thyestes, Hercules on Oeta, Octavia, Harvard University Press, Cambridge, Massachusetts, London, England 2004, p.p. 217-219.

${ }^{3}$ Christofer Collard, Martin Cropp, Euripides Fragments, Aegeus- Meleager, Harvard University Press, Cambridge, Massachusetts, London, England 2008, p.p. 428-431.

${ }^{4}$ Ibid., p.p. 432-433.

${ }^{5}$ Stefano Giazzon, Lodovico Dolce. Tragediografo tra riscrittura dell' antico e traduzione, Dottorato di ricerca, Università degli Studi, Padova 2008, Ludovico Dolce, Tieste, a cura di Stefano Giazzon, Edizioni Res, Torino, 2010 and Ronnie H. Terpening, Ludovico Dolce Renaissance man of Letter, University of Toronto Press, Toronto 1997, p.p. 8-24.

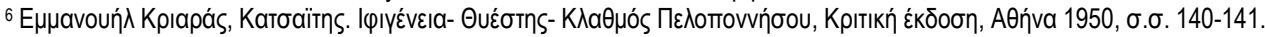


revaluates this particular element from Aeschylus tragedy, Agamemnon ${ }^{1}$. So Katsaitis dares to change the end of the plot, to another different destination from the Italian model and the original myth.

In the 18th century, the German literature was widely considered to be part of that grand project called Enlightenment. To be precise, literature -above all, drama- had gained this particular status (and function) through the poetics of Johann Christoph Gottsched (1700-1766) ${ }^{2}$. According to Gottsched, theatre had the task of communicating to the public the maxims of philosophy which were intended to be useful for the improvement of society. For this purpose, he even aimed at the creation of institutions such as national theatres, thus enhancing the social roles of both playwrights and actors to those of pivotal contributors to the Enlightenment. Of course, not any kind of drama would do for this sublime purpose ${ }^{3}$. From 174145, Gottsched published a collection of model plays, the most famous of which is his own 'Der sterbende Cato' first performed in 1731. But Gottsched was eventually criticized for the supposed dullness of his brand of theatre, above all by Gotthold Ephraim Lessing (1729-1781), who attacked - in his seventeenth of the 'Letters, Concerning the Newest Literature' (1759) - Gottsched's rationalist approach to literature, denying that moral improvement could be reached solely by means of reflection, and underlining the importance of emotions for this purpose. Theatre, according to Lessing, was only effective if it was able to move its audience, the main category in this context being 'Mitleid' (pity, or rather empathy) ${ }^{4}$. Ultimately, this resulted in the emergence of what came to be known as 'bürgerliches Trauerspiel' (domestic or bourgeois tragedy), for only now, the bourgeois spectators were able to watch bourgeois characters (socially like themselves), with a personality composed of both virtues and flaws (anthropologically like themselves), instead of high-born heroes from a distant historical or mythological past, such as Gottsched's own 'Cato', or, say, the assorted protagonists of tragedies by Racine and Corneille. ${ }^{5}$ Taking all of the above into consideration, what is the exact role and position of a play on the subject of Thyestes, in the second half of the 18th Century? After all, it is about a -mythological- subject that certainly does not lend itself easily to identification, given the appalling and in this sense 'indecent' detail of the story. Christian Felix Weiße's 'Atreus und Thyest' was first published in 1766 and premiered in $1767^{6}$. Most notably, Lessing -and Weisse for a while- even entered into something like a private contest, writing literary works about the same or similar subjects. Not surprisingly, the leading part seems to have fallen to Lessing, who was about to become an important innovator of German literature, while Weiße essentially remained where he had positioned himself, that is somewhere between the Gottschedian school of Leipzig and the opposing school of Zürich lead by Johann Jakob Bodmer, who underlined the importance of imagination in literature. There was, however, one field where Weiße played an innovative role ${ }^{7}$.

Lessing, in his turn against neoclassical Gottschedian drama, had praised Shakespearean theatre, with its disregard for restricting poetic rules, as an alternative and better model for the creation of new dramatic works in Germany, ultimately culminating in the 'Sturm-und-Drang' movement. Characteristically, Weiße was denounced for 'classicizing' the

\footnotetext{
${ }_{1}^{1}$ Ronnie H. Terpening, Lodovico Dolce Renaissance man of Letter, ibid., p.p. 262-266.

${ }^{2}$ Gottsched was a student of Christian Wolff (1679-1754), who had made a name for himself by adapting, explaining and popularizing the rationalist philosophy (mainly) of Gottfried Wilhelm Leibniz (1646-1716).

3 In his main work, called 'Versuch einer Critischen Dichtkunst vor die Deutschen' (1729/1730), he laid out a set of rules which was largely based upon French neoclassical theatre, focusing on the three unities of place, time, and action, as well as on categories such as decency or good taste (bienséance) and probability (vraisemblance) in a plot which was supposed to uphold the so called

'Ständeklausel' - in tragedies, only characters of high origin should be on stage, in comedy, only characters of low origin - and cleansed baroque rhetoric or the antics of the Hanswurst, a buffoonish figure from earlier popular theatre. The whole purpose of a play was the illustration of a 'useful' maxim of Enlightenment or a critique of a wrong course of action, which had to be rationally reflected upon by the spectators (who, in doing so, were supposed to 'critically' distance themselves from the performance they were watching) and result in a correction of social behaviour.

${ }^{4}$ Only if the spectator felt that it could be himself or herself suffering, at some point in reality, the fate of a fictional dramatic character, the desired change of his or her behaviour could be achieved. In other words, Lessing strove for the audience's uncompromising identification with the action and, above all, characters on stage.

${ }^{5}$ For this, cf., for instance, Ernst and Erika von Borries, Deutsche Literaturgeschichte. Vol. 2. Aufklärung und Empfindsamkeit, Sturm und Drang, München 1991, especially 33-42 and 81-101.

${ }^{6}$ Its author was born in 1726 and came to Leipzig, then possibly the most important centre of German culture and also domicile of Gottsched, in 1745 in order to attend university there. ${ }^{6} \mathrm{He}$ made the acquaintance of some of the poets and intellectuals who had gathered there, such as Christian Fürchtegott Gellert, Gottlieb Wilhelm Rabener, Ewald von Kleist, Friedrike Caroline Neuber.

${ }^{7}$ Coming from a family of educators, he also soon developed a penchant for pedagogy, working as a private teacher and, above all, being the first one in Germany to write children and youth literature. In addition, he wrote comedies, librettos for operas, but also a series of tragedies. With one of these, his 'Richard III' (1758), Weiße participated in the Shakespeare revival, which was crucial for German literature in the the 18th Century.
} 
Shakespearian model. Thus, Weiße's dramatic work is one of transition: he dares to select a topic which is radical in the sense that it does not conform to bienséance (after all, the plot of 'Richard III.' is one which characterized by mayhem and murder in a ruling dynasty, making it thematically a direct predecessor of the later 'Atreus und Thyest'), but the dramatic execution of the work was, in some regards, deemed insufficient by many of his critics at the time. ${ }^{1}$

'Atreus und Thyest' itself, of course, can be considered the epitome of all family tragedies, exceeding the horrors described in 'Richard III.' by far. ${ }^{2}$ In writing it, Weiße not only based himself upon Hyginus (his main source, where the story of the aftermath of the murderous banquet is told), ${ }^{3}$ but was aware of both the tragedies by Seneca and Crébillon. ${ }^{4}$ This tragedy is among the first ones to be written in iambic pentameters in Germany; it consists of five acts. Its five characters are Atreus, king of Mycenae, his brother Thyest, Pelopia, wife of Atreus, Aegisth, believed to be the son of Atreus, and a priest of Apollo. The first act begins with a monologue of Atreus, his inner self being haunted by the Erinyes (who, already in concordance with the anthropological turn which happened in the $18^{\text {th }}$ century, appear as internal, psychological forces rather than external mythological figures), but not because of his previous evil deeds, but because his odious brother Thyest is still alive. In the following, a priest laments the deplorable state of Mycenae, which is haunted by plagues and starvation, pressing Atreus - who, after all, is to blame for this misery precisely because of his previous evil deeds - to participate in a sacrifice ceremony. Then Aegisth enters, just returning from the oracle of Delphi and revealing its sentence: only blood can purge the blood which has been spilled. The priest suggests that reconciliation and division of power between Atreus and Thyest might lead to salvation for Mycenae. Moreover, Aegisth admits that he has met in Delphi and brought with him to Mycenae Thyest himself. When Atreus reproaches Aegisth for this action, the latter admits that he has acted out of pity. Atreus, however, wants Thyest dead and Aegisth the sole heir to his throne, leaving Aegisth alone to reflect on this strange sentiment of pity induced by Thyest. The second act is predominantly dedicated to the queen and her predicaments. We see her in confrontations with Aigisth, Atreus, and Thyest, by whose presence she is utterly confused. Still, she wants Aegisth to inherit the throne, so she urges him later, in the fourth act, to kill Thyest, revealing to her son that he is indeed not the son of Atreus, a fact unknown to the latter. Queen Pelopia had been raped shortly before her marriage by an unknown assailant, from whom however she only had managed to take his sword. She threatens to tell Atreus, if Aegisth does not oblige to her command. The dramatic action culminates in the fifth act.: Aegisth tries to murder Thyest in his sleep, but does not succeed. Awake, Thyest, talks to him and recognizes the sword by means of which he was supposed to die - it is the very sword the queen had taken from her then unknown rapist, it was Thyest himself, making him the real father of Aegisth. But not enough: the queen, whose own origins were unknown to herself, actually be the daughter of Thyest, making him also the grandfather of Aegisth! The story of murder has evolved into one of incest. Queen Pelopia, haunted by her internal Erinyes, kills herself with the ominous sword; Aegisth pulls it out of her lifeless body, slaying, in turn Atreus. Thyest is in despair: The curse of the House of Pelops will continue! ${ }^{5}$

\footnotetext{
${ }^{1}$ As it was not possible to situate Weiße neither in the category of the Gottschedians (for a long time considered outdated and thus 'bad') nor into the 'new era', embodied in Lessing and then in the poets of the Sturm-und-Drang, he was almost forgotten by literary history in the $19^{\text {th }}$ and early $20^{\text {th }}$ centuries. (Cf. Jürgen Krätzer, Christian Felix Weiße in der deutschen Germanistik. Ein Forschungsbericht, in: Anneliese Klingenberg, Katharina Middell, Matthias Middel, Ludwig Stockinger (eds.), Sächsische Aufklärung, Leipzig: Leipziger Universitätsverlag 2001, 147-160.) Even the renowned literary scholar Jakob Minor who dedicated a monograph to this author - which still has to be considered a work of reference for Weiße - applies these categories and thus certainly does not do full justice to Weiße. For Lessing's critique, cf. Jakob Minor, Christian Felix Weiße und seine Beziehungen zur deutschen Literatur des 18. Jahrhunderts, Innsbruck: Wagner, 1880, 206-212, and Georg-Michael Schulz, Tugend, Gewalt und Tod. Das Trauerspiel der Aufklärung und die Dramaturgie des Pathetischen und des Erhabenen, Tübingen, Niemeyer: 1988, 263-265.

2 It should be mentioned here that family conflicts were an main topic in German Drama between the 1750s and the 1770s. The gruesomeness of the Atreus and Thyestes plot is, on stage, maybe paralleled only by Gerstenberg's 'Ugolino' (1768), where, following an episode from Dante's 'Inferno', the starvation death of Count Ugolino and his sons in a prison tower are described, including an episode of cannibalism.

${ }^{3}$ Cf. Günter Dammann, Christian Felix Weiße. Atreus und Thyest (1766). Die Aktualisierung Senecas im Trauerspiel der deutschen Aufklärung, in: Gerhard Lohse, Solveig Malatrait (eds.), Die griechische Tragödie und ihre Aktualisierung in der Moderne. Zweites BrunoSnell-Symposium der Universität Hamburg am Europa-Kolleg, München, Saur: 2006, 67-100, here 72f.

${ }^{4}$ Cf. Günter Dammann, Christian Felix Weiße. Atreus und Thyest (1766). Die Aktualisierung Senecas im Trauerspiel der deutschen Aufklärung, in: Gerhard Lohse, Solveig Malatrait (eds.), Die griechische Tragödie und ihre Aktualisierung in der Moderne. Zweites BrunoSnell-Symposium der Universität Hamburg am Europa-Kolleg, München, Saur: 2006, 67-100, here 69f.

5 The text of the play can be found in: Christian Felix Weiße, Atreus und Thyest. Ein Trauerspiel in fünf Aufzügen. Aus dem Jahre 1766, in: Fritz Brüggemann (ed.), Das Drama des Gegeneinander in den sechziger Jahren. Trauerspiele von Christian Felix Weiße, Darmstadt
} 
Christian Felix Weiße, in this tragedy distinguished by violent outbursts of furor, offers an array of different characters ${ }^{1}$. In the times of Enlightenment, is not simply one-dimensional, but the author -deliberately- poses a problem concerning the era's fundamentally optimistic view of humanity. How is it, that man, who is supposed to be fundamentally good (albeit flawed), can manifest itself as pure evil? Basically, with Atreus, Weiße shows the frailty of the human condition, how nature and reason are constantly endangered by irrationality, which is at the bottom of the (unnatural) furor displayed. Thyest, on the other hand, may also be an evildoer from the paternal generation, but some of his crimes can at least be explained (this is done in some flashbacks in the play), and above all, he displays remorse. In this way, he can evoke pity, thus making him compatible with the main task of theatre according to Lessing. In contrast, young Aegisth, is an essentially naive and weak character, who almost lets himself get tricked into murdering Thyest. His actual slaying of Atreus, on the other hand, Aegisth perceives as a just punishment for that man. The most complex character, who is brought to the foreground of the myth only by Weiße, is the one of queen Pelopia, who is - in a distorted, incestuous manner blurring the boundaries between the generations - daughter, wife and mother in one person. Both of these - in this sense - younger figures are already determined by the sentimentalism which characterizes the later phase of the Enlightenment, beginning with Rousseau. And both of them are characters, who are essentially good from the outset, but are involved and induced due to circumstances to do evil deeds, both of them, as it were, losing their innocence ${ }^{2}$.

Weiße uses this mythical plot from Greek antiquity, and its seemingly anachronistic and atavistic elements, endowed with characters who are all, to a varying degree, evil or at least scarred not in order to contradict Enlightenment, but rather to show its constant endangerment, to make, as it were, a constant appeal to his spectators to not let down their guards, to constantly make efforts in the 'enlightened' process of creating a better future for humanity. After all, we had pointed out before that Weiße always wrote literature with his audience in mind, always trying to reach some pedagogical effect in his readers. And, indeed, his plays reached a high degree of popularity during the decade between 1766 and $1776,{ }^{3}$ only to be forgotten - unjustly - in later years.

Along with Dolce and Weiße, who composed a tragedy with the title Tieste, is Ugo Foscolo ${ }^{4}$. The drama was presented for first time in 1797, at Sant' Angelo Theatre in Venice. This tragedy is the first dramatic work of the author. It is indicative of his negative opinion of the tragedies of Crebillon and Voltaire, composed in 1707 and $1771^{5}$. Foscolo's text has a strong political character, because it promotes the poet's belief against tyranny. Atreus is the incarnation of the regime, but Foscolo doesn't follow the tradition of Seneca or Dolce's in his plot. First of all the hero is only 24 or 26 years old, much younger than the protagonist in Dolce's or Katsaitis' works. In Foscolo's tragedy there is also present the figure of Aërope, Atreus' wife, who has a baby child 4 years old with Tieste, and lives imprisoned in the palace of her husband. Tieste doesn't know anything about his son. Aërope decided to kill herself and the child, in order to save him from Atreus' tortures. Hippodamia, the mother in law, tries to save her and the kid, and promises to speak to the king. Tieste returns to save his love, meets his mother and asks her help also. Atreus gets his opportunity for revenge: he pretends that he forgives the couple, kills the baby, and offers his blood mixed with wine to the tragic father. At the end of the story, the queen dies from pain, and Tieste kills himself. Except the political message against tyranny, Foscolo connects Love with Death, and shows how the

1964, 238-304. For another summary of the text, cf. also Jan-Oliver Decker, Weiße, Christian Felix (1726-1804). Atreus und Thyest. Ein Trauerspiel in fünf Aufzügen, in: Heide Hollmer, Albert Meier (eds.), Dramenlexikon des achtzehnten Jahrhunderts, München: Beck, 2001, 323-325; for a short anglophone account, cf. Robert R. Heitner, German Tragedy in the Age of Enlightenment. A Study in the Development of Original Tragedies 1724 - 1768, Berkeley: University of California Press, 1963, 271-278.

${ }^{1}$ As is often the case in dramatic works from the 1760 s and 1770 s, the generation of the fathers is one characterized by guilt. In this context, it is Atreus who embodies - in a way similar to Richard III. and other 'anti-heroes' of Weiße - absolute evil.

2 This paragraph is based upon Günter Dammann, Christian Felix Weiße. Atreus und Thyest (1766). Die Aktualisierung Senecas im Trauerspiel der deutschen Aufklärung, in: Gerhard Lohse, Solveig Malatrait (eds.), Die griechische Tragödie und ihre Aktualisierung in der Moderne. Zweites Bruno-Snell-Symposium der Universität Hamburg am Europa-Kolleg, München, Saur: 2006, 67-100, here 78-82. For the role of the emotions in the play cf. Ulrich Port, Pathosformeln. Die Tragödie und die Geschichte exaltierter Affekte (1755-1888), München: Fink, 2005, 122-134, as well as Georg-Michael Schulz, Tugend, Gewalt und Tod. Das Trauerspiel der Aufklärung und die Dramaturgie des Pathetischen und des Erhabenen, Tübingen, Niemeyer: 1988, 263-270.

${ }^{3}$ Cf., for instance, Jakob Minor, Weiße, Christian Felix, in: Allgemeine Deutsche Biographie Band 41, Leipzig:Duncker \& Humblot, 1896 , 587-590, here 590 .

4 Ugo Foscolo, Poesie e Tragedie, Vol. I, edizione diretta da Franco Gavazzeni, con la collaborazione di Maria Maddalena Lombardi e Franci Longon, Biblioteca della Pleiade, Einaudi- Gallimard, Torino 1994, p.p. 171-234.

${ }^{5}$ Carla Doni, II Mito Greco nelle Tragedie di Ugo Foscolo, Bulzoni Editore, Roma 1997, p.11 
passion guides to the fatal end of life. In this drama is relevant the presence of a particular female figure, story of the Atrides House.

In conclusion, we will take a short look at the relation between the works and their audience within the different sociocultural contexts which are relevant for our topic. During the times of Antiquity, theatrical production was strictly connected to the political situation. Through the tragedies or comedies, the tears and the laughter, the messages were traveling from the stage to the audience and vice versa. With the end of the Golden Ages for the theater, the interest for the Greek and Latin tragedies gradually disappears for many centuries until the period of the Renaissance, when the Italian humanists revaluated the Latin comedy according to Plautus and Terentius example. But the discovery of the great tragic poets of Greece was the most important motive for the cultural explosion in Italy of the $16^{\text {th }}$ century. At the beginning, writers and audience approached the Greek theater as a high quality product of literature with the proper respect; however, they were limited only to read, study and discuss these texts at the palaces and courts when the high class was gathering together. A few years later, Italian authors started composing their own theatrical work steadily influenced by the classic style. Their first efforts were also subjects of study, but not for performance. The level of this particular production was not high because it was based either on translation or revision of the Greek tragedies and for that reason works of that kind were called "volgarizzamenti" (vernacularizations). Performances were taking place in the palaces only for the aristocracy because only they were educated enough and able to understand the language and the deeper meaning of the theatrical project case. Therefore, the motives of writing during those times in Italy were totally different from that of the Greek and Roman period. Also, the purpose of writing became different. Revisions and performances of ancient tragedy in Italy targeted not only to the simple imitation but to the representation of a whole world on the scene not very different from their current reality. Morphological, thematic, and scenic innovations of theater bridged the gap between facts of the scene and the real world. Writers were taking care to incorporate in their plots concerns about the social and political situation of that time and elements that satisfy the aesthetic expectations of the audience. One of the most important popular themes of Renaissance's tragedies is the sense of Kingdom and the ideal leader, a clearly political subject that derives from Machiavelli's theories. In these tragedies, Kings tended to ignore the rules of the right governance; they used to act with immorality and practiced Machiavelli's doctrines. An excellent example of the abovementioned behavior can be found in Thiestes of L. Dolce and also in the Greek version of P. Katsaitis that also refer to Machiavelli's political thoughts: for example the dialogue between Atreus and his Consultant (verses 321-341).

German Enlightenment theatre - and with it Weiße's version of the myth - emphasizes a didactic approach: the story of Thyest, even though taking place in antiquity, is of utter relevance for the contemporary - now predominantly bourgeois -audience in the $18^{\text {th }}$ century. Similar to the domestic tragedies - also with a focus on family constellations - it focuses on the delicate balance of reason and sentiment, demonstrating the former's constant endangerment by an excess of pathos.

In Euripides' lost play "The Cretans" (Kretes) ${ }^{1}$, a fragment based on the stories associated with Minos' family in Crete, one can read a tremendous sentence referring to the House of Atreus: "In the House of Atreus there is no trace left of Atreus anymore: The blood of Thyestes triumphed". In the myth of Atreus' family, it is Thyestes that holds the role of key character. Of course, Atreus is a central character; however, when the Mother of all Tragedies -the history of the Pelopides- will be rebuilt from fragments, episodes and texts, it will be the character of Thyestes and not of Atreus, who is the one to characterize these works in the centuries to come. Thyestes becomes the center of the storyline. More than 35 writers -and certainly not only Katsaitis, Weiße, and Foscolo - inspired by both the myth and their respective socio-cultural realities, use Thyestes as a symbolic figure for confronting and denouncing the phenomenon of tyranny, be it on a political, a philosophical or an anthropological level.

\section{${ }^{*}$ About Authors}

Prof. Maria Sgouridou:

1998: PhD (Dante's influence in Neohellenic Literature) at the Aristotle University of Thessaloniki. She teaches at the University of Athens (Faculty of Arts and Philosophy, Department of Italian Studies) the following subjects: Comparative Literature, Introductory Course on the Italian Theater, Monographic Course on Foscolo and Influences of the Italian Theater (16th - 18th sec.) on the Islands of the lonian (post-lauream course).

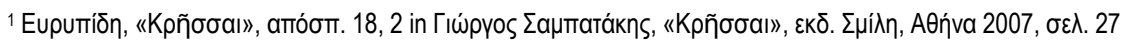


2013-Today: Associate Professor; she has published eight books from 2001 to 2017 (four of them concern Ugo Foscolo's works), 75 articles and numerous appearances - interventions on national and international conferences.

\section{Prof. Stefan Lindinger:}

$\mathrm{PhD}$ University of Chicago. He taught German as a foreign language at the University of Chicago and at the University of Pisa. He is Assistant Professor of German Literature at the National and Kapodistrian University of Athens. He has published several books and articles on various subjects focusing on the German literature of 1700 and 1800.

\section{Dr. Georgios Bitsakos:}

Graduated in Archeology and History of Greek Art from the University of Florence. Graduated in Italian Language and Literature at the National and Kapodistrian University of Athens. At the same university, he received the Master's degree in "Roman, Italian and Greek Studies: Literature, History and Civilization". He teaches Italian language and he is qualified as a Tourist Guide specializing in people with disabilities. He authored articles and he presented his studies on Dante Alighieri, G. Boccaccio, N. Machiavelli, P. Aretino, V. Alfieri, Ugo Foscolo, G. d'Annunzio in various congresses. He currently works on his PhD in the Department of Italian Studies at the University of Athens.

\section{Bibliography}

[1] Christian Felix Weiße, Atreus und Thyest. Ein Trauerspiel in fünf Aufzügen. Aus dem Jahre 1766, in: Fritz Brüggemann (ed.), Das Drama des Gegeneinander in den sechziger Jahren. Trauerspiele von Christian Felix Weiße, Darmstadt 1964, 238-304.

[2] Ernst and Erika von Borries, Deutsche Literaturgeschichte. Vol. 2. Aufklärung und Empfindsamkeit, Sturm und Drang, München 1991.

[3] Günter Dammann, Christian Felix Weiße. Atreus und Thyest (1766). Die Aktualisierung Senecas im Trauerspiel der deutschen Aufklärung, in: Gerhard Lohse, Solveig Malatrait (eds.), Die griechische Tragödie und ihre Aktualisierung in der Moderne. Zweites Bruno-Snell-Symposium der Universität Hamburg am Europa-Kolleg, München, Saur: 2006, 67-100.

[4] Robert R. Heitner, German Tragedy in the Age of Enlightenment. A Study in the Development of Original Tragedies 1724 - 1768, Berkeley: University of California Press, 1963.

[5] Jan-Oliver Decker, Weiße, Christian Felix (1726-1804). Atreus und Thyest. Ein Trauerspiel in fünf Aufzügen, in: Heide Hollmer, Albert Meier (eds.), Dramenlexikon des achtzehnten Jahrhunderts, München: Beck, 2001.

[6] Jürgen Krätzer, Christian Felix Weiße in der deutschen Germanistik. Ein Forschungsbericht, in: Anneliese Klingenberg, Katharina Middell, Matthias Middel, Ludwig Stockinger (eds.), Sächsische Aufklärung, Leipzig: Leipziger Universitätsverlag 2001, 147-160.

[7] Jakob Minor, Christian Felix Weiße und seine Beziehungen zur deutschen Literatur des 18. Jahrhunderts, Innsbruck: Wagner, 1880.

[8] Jakob Minor, Weiße, Christian Felix, in: Allgemeine Deutsche Biographie Band 41, Leipzig: Duncker \& Humblot, 1896, 587-590.

[9] Walter Pape, 'Ein billetdoux an die ganze Menschheit'. Christian Felix Weiße und die Aufklärung, in: Wolfgang Martens (ed.), Leipzig. Aufklärung und Bürgerlichkeit (= Zentren der Aufklärung 3), Heidelberg: Schneider, 1990, 267-295.

[10] Ulrich Port, Pathosformeln. Die Tragödie und die Geschichte exaltierter Affekte (1755-1888), München: Fink, 2005.

[11] Georg-Michael Schulz, Tugend, Gewalt und Tod. Das Trauerspiel der Aufklärung und die Dramaturgie des Pathetischen und des Erhabenen, Tübingen, Niemeyer: 1988.

[12] John G. Fitch, Seneca. Oedipus. Agamemnon, Thyestes, Hercules on Oeta, Octavia, Harvard University Press, Cambridge, Massachusetts, London, England 2004.

[13] Christofer Collard, Martin Cropp, Euripides Fragments, Aegeus- Meleager, Harvard University Press, Cambridge, Massachusetts, London, England 2008. 
[14] Stefano Giazzon, Lodovico Dolce. Tragediografo tra riscrittura dell' antico e traduzione, Dottorato di ricerca, Università degli Studi, Padova 2008, Ludovico Dolce, Tieste, a cura di Stefano Giazzon, Edizioni Res, Torino, 2010.

[15] Ronnie H. Terpening, Lodovico Dolce Renaissance man of Letter, University of Toronto Press, Toronto 1997.

[16] Ugo Foscolo, Poesie e Tragedie, Vol. I, edizione diretta da Franco Gavazzeni, con la collaborazione di Maria Maddalena Lombardi e Franci Longon, Biblioteca della Pleiade, Einaudi- Gallimard, Torino 1994.

[17] Carla Doni, II Mito Greco nelle Tragedie di Ugo Foscolo, Bulzoni Editore, Roma 1997.

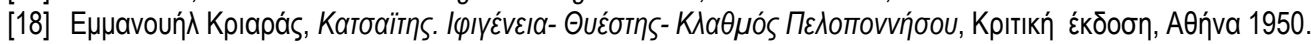

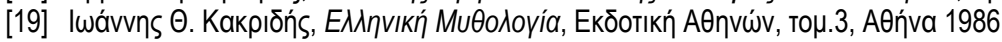

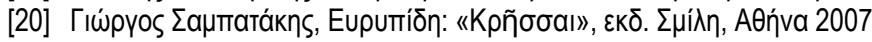

